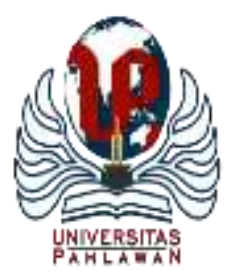

\title{
JURNALBASICEDU
}

Volume 5 Nomor 6 Tahun 2021 Halaman 5968 - 5975

Research \&Learningin Elementary Education https://jbasic.org/index.php/basicedu

\section{Penerapan Model Pembelajaran Multiliterasi untuk Meningkatkan Keterampilan Berpikir Tingkat Tinggi (HOTS) Mahasiswa Pendidikan Guru Sekolah Dasar}

\author{
Khoimatun $^{1 凶}{ }^{凶}$, Asrizal Wahdan Wilsa ${ }^{2}$ \\ Program Studi Pendidikan Guru Sekolah Dasar, STKIP Nahdlatul Ulama Indramayu, Indonesia ${ }^{1,2}$ \\ E-mail: khoimatun.83@gmail.com ${ }^{1}$, asrizalwahdanwilsa@stkipnu.ac.id ${ }^{2}$
}

\begin{abstract}
Abstrak
Penelitian ini bertujuan untuk mengetahui pengaruh penerapan model pembelajaran multiliterasi terhadap keterampilan berpikir tingkat tinggi (HOTS) Mahasiswa PGSD STKIP Nahdlatul Ulama Indramayu. Penelitian ini menggunakan metode quasy-eksperimen dengan pretest-postest control group design. Populasi dalam penelitian ini yaitu seluruh mahasiswa semester V Program Studi Pendidikan Guru Sekolah Dasar STKIP Nahdlatul Ulama Indramayu sebanyak 3 kelas. Subjek penelitian yaitu mahasiswa semester V Program Studi S1 PGSD STKIP Nahdlatul Ulama Indramayu sebanyak 2 kelas dengan jumlah 60 mahasiswa. Teknik pengumpulan data meliputi Metode Tes. Instrumen yang digunakan dalam penelitian ini yaitu soal tes. Teknik analisis data yang digunakan yaitu teknik Kolmogrof Smirnov. Berdasarkan hasil analisis data, dapat disimpulkan bahwa penerapan model pembelajaran multiliterasi berpengaruh terhadap keterampilan berpikir tingkat tinggi (HOTS) mahasiswa. Adanya pengaruh tersebut ditunjukkan oleh perbedaan keterampilan berpikir tingkat tinggi (HOTS) mahasiswa kelas eksperimen dan kelas kontrol.
\end{abstract}

Kata Kunci: Multiliterasi, HOTS, Mahasiswa

\begin{abstract}
This study aims to determine the effect of the application of the Multiliterate Learning Models on High Order Thinking Skills (HOTS) Ability Students of PGSD STKIP Nahdlatul Ulama Indramayu. This study uses a quasiexperimental method with a pretest-posttest control group design. The population in this study were all students of the fifth semester PGSD Study Program of STKIP Nahdlatul Ulama Indramayu as many as 3 classes. The research subjects are students of the fifth semester of the PGSD S1 Study Program, STKIP Nahdlatul Ulama Indramayu as many as 2 classes with a total of 60 students. Data collection techniques include the Test Method. The instruments used in this study were test questions. The data analysis technique used is the Kolmogrof Smirnov technique. Based on the results of data analysis, it can be concluded that the application of the Multiliteration Learning Model has an effect on High Order Thinking Skills (HOTS) Student Ability. The existence of this influence is indicated by differences in student High Order Thinking Skills Ability in the experimental and control class.
\end{abstract}

Keywords: Multiliterate, HOTS, Students

Copyright (c) 2021 Khoimatun, Asrizal Wahdan Wilsa

$\triangle$ Corresponding author :

Email : khoimatun.83@gmail.com

DOI : https://doi.org/10.31004/basicedu.v5i6.1603

ISSN 2580-3735 (Media Cetak)

ISSN 2580-1147 (Media Online)

Jurnal Basicedu Vol 5 No 6 Tahun 2021

p-ISSN 2580-3735 e-ISSN 2580-1147 


\section{PENDAHULUAN}

Pembelajaran di perguruan tinggi merupakan suatu rangkaian peristiwa yang kompleks dan sistematis. Dalam peristiwa tersebut terjadi serangkaian proses yang harus dilalui untuk mencapai tujuan belajar yang diharapkan. Serangkian proses yang dilalui oleh mahasiswa dalam pembelajaran tersebut dapat menghasilkan suatu keterampilan. Salah satu keterampilan dasar yang dimiliki oleh mahasiswa yaitu keterampilan literasi. Keterampilan literasi merupakan keterampilan untuk mencari sumber pengetahuan dasar mahasiswa. Dengan melakukan literasi, mahasiswa akan mengalami proses dan memiliki keterampilan berpikir untuk membentuk dan mengembangkan pengetahuannya. Salah satu keterampilan berpikir yang dapat dikembangkan dengan literasi yaitu keterampilan berpikir tingkat tinggi (HOTS). Menurut Newman dan Wehlage dalam Widodo \& Kadarwati (2013) menyatakan bahwa dengan high order thinking peserta didik akan dapat membedakan ide atau gagasan secara jelas, berargumen dengan baik, mampu memecahkan masalah, mampu mengkonstruksi penjelasan, mampu berhipotesis dan memahami hal-hal kompleks menjadi lebih jelas.

Morocco, dkk dalam Yunus Abidin (2016) menegaskan bahwa dalam abad ke-21 terdapat empat kompetensi penting yang harus dimiliki oleh manusia yakni kompetensi pemahaman yang tinggi, kompetensi berpikir kritis, kompetensi kolaborasi dan kompetensi berkomunikasi. Keempat kompetensi tersebut tidak akan terlepas dari keterampilan literasi yang menyertainya. Berdasarkan pernyataan tersebut, jelas bahwa salah satu upaya untuk meningkatkan keterampilan berpikir tingkat tinggi mahasiswa salah satunya yaitu melalui literasi. Secara istilah, literasi didefinisikan sebagai kemampuan memahami simbol-simbol bahasa atau kemampuan keaksaraan. Berdasarkan cakupan awalnya, literasi dipandang sebagai kondisi melek huruf, melek kata, dan melek makna. Dalam perkembangannya, literasi yang digunakan dalam berbagai bidang ilmu tersebut menggunakan berbagai media sebagai alat komunikasi dan pembentukan makna. Upaya penyampaian informasi bisa dilakukan melalui berbagai media sehingga tulisan tidak bisa dibatasi hanya sekedar tata bahasa linguistik, melainkan melewati batas-batas tata bahasa lingustik. Pandangan ini kemudian melahirkan istilah metabahasa, teks multimodal, dan akhirnya berujung pada konsep multiliterasi (Untari, 2017).

Konsep multiliterasi menurut Yunus Abidin (2014) merupakan pembelajaran yang menempatkan kemampuan membaca, menulis, menyimak, dan berbicara seefisien mungkin untuk meningkatkan kemampuan berpikir meliputi kemampuan mengkritisi, menganalisis, dan mengevaluasi informasi dari berbagai sumber dalam berbagai ragam disiplin ilmu dan kemampuan mengkomunikasikan informasi tersebut. Senada dengan hal tersebut. Keterampilan literasi harus dimiliki oleh mahasiswa. Keterampilan tersebut dipandang sebagai dasar bagi mahasiswa untuk dapat membentuk dan mengembangkan pengetahuannya baik secara mandiri ataupun secara kolaboratif. Dafit (2017) menyatakan bahwa multiliterasi merupakan paradigma baru dalam pembelajaran literasi. Paradigma tersebut harus disikapi dengan baik oleh mahasiswa sebagai salah satu upaya untuk meningkatkan kemampuan belajarnya. Dengan menggunakan multiliterasi, mahasiswa mampu belajar dan memahami berbagai macam konsep dengan lebih bermakna karena menggunakan berbagai macam sumber daya untuk memperoleh pengetahuannya sehingga keterampilan berpikir tingkat tinggi (HOTS) mahasiswa dapat mengalami peningkatan. Mahasiswa di sisi lain juga semestinya terlibat secara aktif, mandiri dalam belajar, dan memanfaatkan berbagai jenis teks yang beragam dalam konsep multiliterasi sebagai referensi pengetahuan sekaligus wujud praktik kerja dalam melaksanakan tugas perkuliahan (Swatika Sari et al., 2013).

Revisi teksonomi bloom yang dilakukan oleh Anderson dan Krathwohl lebih berfokus pada bagaimana domain kognitif lebih hidup dan aplikatif bagi pendidik dan praktik pembelajaran yang diharapkan dapat membantu pendidik dalam mengolah dan merumuskan tujuan pembelajaran dan strategi penilaian yang efisien. Ketiga konsep di atas yang menjadi dasar high order thinking skills merujuk pada aktivitas menganalisis, mengevaluasi, mencipta pengetahuan yang disesuaikan dengan konseptual, prosedural dan metakognitif. Menurut Krathwohl (2002) dalam A revision of Bloom's Taxonomy, menyatakan bahwa 
5970 Penerapan Model Pembelajaran Multiliterasi untuk Meningkatkan Keterampilan Berpikir Tingkat Tinggi (HOTS) Mahasiswa Pendidikan Guru Sekolah Dasar - Khoimatun, Asrizal Wahdan Wilsa DOI: https://doi.org/10.31004/basicedu.v5i6.1603

indikator untuk mengukur kemampuan berpikir tingkat tinggi meliputi menganalisis (C4) yaitu kemampuan memisahkan konsep ke dalam beberapa komponen dan menghubungkan satu sama lain untuk memperoleh pemahaman atas konsep secara utuh, mengevaluasi (C5) yaitu kemampuan menetapkan derajat sesuatu berdasarkan norma, kriteria atau patokan tertentu, dan mencipta (C6) yaitu kemampuan memadukan unsurunsur menjadi sesuatu bentuk baru yang utuh dan luas, atau membuat sesuatu yang orisinil.

Pada kenyataannya, keterampilan berpikir tingkat tinggi (HOTS) mahasiswa masih belum berkembang dengan baik. Hal tersebut disebabkan oleh model pembelajaran yang digunakan mahasiswa masih menggunakan model pembelajaran konvensional dan belum mengedepankan mahasiswa untuk berpikir tingkat tinggi sehingga keterampilan berpikir tingkat tinggi mahasiswa tidak berkembang. Hartati (2020) menyatakan bahwa guru sekolah dasar seyogyanya meningkatkan kualitas pembelajaran berbasis karakter, multiliterasi, dan keterampilan berpikir tingkat tinggi dalam rangka menjawab tantangan abad 21 yang sering disebut sebagai abad industri 4.0. Sebagai calon guru pendidikan dasar yang mampu menjawab tantangan abad 21 tersebut, mahasiswa tentu dituntut untuk memiliki keterampilan berpikir tingkat tinggi sebelum menerapkan keterampilan tersebut kepada peserta didiknya kelak. Oleh sebab itu diperlukan upaya untuk meningkatkan keterampilan berpikir tingkat tinggi (HOTS) mahasiswa.

Berbagai penelitian relevan yang sesuai dengan permasalahan tersebut yaitu penelitian Rahman \& Damaianti (2019) yang menyatakan bahwa model multiliterasi kritis sebagian besar menujukkan keberhasilan dalam proses pembelajaran dan hasil pembelajarannya. Sementara itu, Dinni (2018) menyatakan bahwa kemampuan literasi matematika dan high order thinking skills tidak hanya terbatas pada kemampuan berhitung saja, namun juga bagaimana menerapkan matematika dalam kehidupan sehari-hari guna menyelesaikan suatu permasalahan, bagaimana mengkomunikasikannya, dengan demikian maka dapat dilihat bagaimana proses berpikir matematisasi peserta didik. Senada dengan itu, Kurniasih (2019) menyatakan bahwa bahwa untuk mengembangkan multiliterasi dan kemampuan berpikir tingkat tinggi, pembelajaran terpadu merupakan salah satu pendekatan pembelajaran yang disarankan untuk diterapkan.

Berdasarkan uraian dan permasalahan di atas, perlu dilakukannya penelitian untuk meningkatkan keterampilan berpikir tingkat tinggi (HOTS) mahasiswa dengan menggunakan model literasi. Penelitian ini bertujuan untuk mengetahui perbedaan keterampilan berpikir tingkat tinggi (HOTS) mahasiswa setelah diterapkannya model pembelajaran multiliterasi.

\section{METODE PENELITIAN}

Penelitian ini merupakan penelitian eksperimen dengan desain pretest-postest control group design. Populasi penelitian ini yaitu seluruh Mahasiswa Semester V Program Studi Pendidikan Guru Sekolah Dasar STKIP Nahdlatul Ulama Indramayu. Sampel penelitian ini yaitu mahasiswa semester V Program Studi Pendidikan Guru Sekolah Dasar sebanyak 2 kelas dengan jumlah 60 mahasiswa. Variabel bebas dalam penelitian ini adalah model pembelajaran multiliterasi. Variabel terikat adalah keterampilan berpikir tingkat tinggi (HOTS). Data meliputi keterampilan berpikir tingkat tinggi (HOTS) mahasiswa. Teknik pengumpulan menggunakan metode tes. Instrumen yang digunakan dalam penelitian ini yaitu berupa soal tes keterampilan berpikir tingkat tinggi. Teknik analisis data yang digunakan yaitu teknik Kolmogrof Smirnov.

\section{HASIL DAN PEMBAHASAN}

Kegiatan pembelajaran yang dilakukan selama kegiatan penelitian berlangsung yaitu menggunakan model pembelajaran multiliterasi untuk kelas eksperimen sementara untuk kelas kontrol menggunakan model pembelajaran konvensional. Untuk mengetahui pengaruh penerapan model pembelajaran mulliterasi terhadap keterampilan berpikir tingkat tinggi (HOTS) mahasiswa digunakan metode tes. Tes tersebut dilaksanakan 
5971 Penerapan Model Pembelajaran Multiliterasi untuk Meningkatkan Keterampilan Berpikir Tingkat Tinggi (HOTS) Mahasiswa Pendidikan Guru Sekolah Dasar - Khoimatun, Asrizal Wahdan Wilsa DOI: https://doi.org/10.31004/basicedu.v5i6.1603

sebelum dan sesudah proses pembelajaran (pretest-posttest). Dengan menggunakan instrumen tes berupa soal tes yang sama pada kelas eksperimen dan kontrol maka dapat diperoleh data mengenai perbedaan keterampilan berpikir tingkat tinggi (HOTS) mahasiswa. Data tersebut kemudian diolah dan diuji untuk menjawab rumusan masalah apakah terdapat perbedaan keterampilan berpikir tingkat tinggi (HOTS) mahasiswa setelah diterapkannya pembelajaran dengan menggunakan model multiliterasi.

Hasil uji normalitas menunjukkan bahwa sig. $>\alpha$ masing-masing variabel terletak dibawah penolakan yang ditentukan sig. Hasil uji normalitas data kelas eksperimen memperoleh hasil sebesar 0,149 dan kelas kontrol memperoleh hasil sebesar 0,075 dengan taraf signigikansi $\alpha=0,05$ maka kedua data hasil uji normalitas data kelas eksperimen dan kelas kontrol tersebut $>\alpha$. Dengan demikian dapat disimpulkan bahwa kedua subjek penelitian berasal dari populasi yang berdistribusi normal. Data hasil uji normalitas disajikan pada gambar berikut.

Tests of Normality

\begin{tabular}{|l|r|r|r|r|r|r|}
\hline & \multicolumn{3}{|c|}{ Kolmogorov-Smirnov $^{\mathrm{a}}$} & \multicolumn{3}{c|}{ Shapiro-Wilk } \\
\cline { 2 - 7 } & Statistic & \multicolumn{1}{|c|}{$\mathrm{df}$} & \multicolumn{1}{c|}{ Sig. } & \multicolumn{1}{c|}{ Statistic } & \multicolumn{1}{c|}{ df } & \multicolumn{1}{c|}{ Sig. } \\
\hline Eksperimen & .148 & 26 & .149 & .915 & 26 & .034 \\
Kontrol & .163 & 26 & .075 & .910 & 26 & .026 \\
\hline
\end{tabular}

a. Lilliefors Significance Correction

\section{Gambar 1: Hasil Uji Normalitas Data}

Berdasarkan hasil uji normalitas tersebut, karena kedua data berdistribusi normal, maka dilanjutkan uji homogenitas. Hasil uji homogenitas disajikan pada gambar berikut.

Test of Homogeneity of Variance

\begin{tabular}{|ll|r|r|r|r|}
\hline & \multicolumn{1}{|c|}{$\begin{array}{l}\text { Levene } \\
\text { Statistic }\end{array}$} & \multicolumn{1}{c|}{ df1 } & \multicolumn{1}{c|}{ df2 } & \multicolumn{1}{c|}{ Sig. } \\
\hline HOTs & Based on Mean & .004 & 1 & 56 & .950 \\
& Based on Median & .014 & 1 & 56 & .906 \\
& Based on Median and & .014 & 1 & 54.587 & .906 \\
& with adjusted df & .003 & 1 & 56 & .955 \\
& Based on trimmed mean & & \\
\end{tabular}

Gambar 2: Hasil Uji Homogenitas

Berdasarkan hasil uji normalitas dengan kriteria nilai sig. Based on Mean > 0,05 maka varians data homogen. Maka dari itu, berdasarkan hasil analisis data homogenitas di atas diperoleh nilai sig. Based on Mean 0,950 > 0,05 maka dapat disimpulkan bahwa varians data tersebut homogen. Karena menghasilkan varians data yang homogen, untuk mengetahui apakah terdapat perbedaan rata-rata (mean) antara kedua populasi dengan membandingkan nilai rata-rata dari sampel yang diuji, maka uji selanjutnya yang digunakan yaitu uji $t$.

\section{Perbedaan Keterampilan Berpikir Tingkat Tinggi (HOTS) Mahasiswa Kelas Eksperimen dan Kontrol}

Keterampilan berpikir tingkat tinggi (HOTS) mahasiswa diukur dengan menggunakan teknik tes berupa instrumen soal tes pada mata kuliah pembaharuan dalam PBM materi model pembelajaran tematik reliabel sebanyak 9 soal. Soal tes yang digunakan mengacu pada indikator untuk mengukur keterampilan berpikir tingkat tinggi menurut Krathwohl dalam Purbaningrum (2017) meliputi:

1) Menganalisis (analyzing) 
5972 Penerapan Model Pembelajaran Multiliterasi untuk Meningkatkan Keterampilan Berpikir Tingkat Tinggi (HOTS) Mahasiswa Pendidikan Guru Sekolah Dasar - Khoimatun, Asrizal Wahdan Wilsa DOI: https://doi.org/10.31004/basicedu.v5i6.1603

a. Menganalisis informasi yang masuk dan membagi-bagi atau menstrukturkan informasi ke dalam bagian yang lebih sederhana untuk mengenali pola atau hubungan yang ada.

b. Mampu mengenali dan membedakan faktor penyebab dan akibat dari sebuah skenario yang rumit.

c. Mengidentifikasi / merumuskan pertanyaan

2) Mengevaluasi (evaluating)

a. Memberikan penilaian terhadap solusi, gagasan, dan metodologi dengan menggunakan kriteria yang cocok atau standar yang ada untuk memastikan nilai efektivitas atau manfaatnya.

b. Membuat hipotesis, mengkritik dan melakukan pengujian

c. Menerima atau menolak sesuatu pernyataan berdasarkan kriteria yang telah ditetapkan

3) Mengkreasi (creating)

a. Membuat generalisasi suatu ide atau cara pandang terhadap sesuatu.

b. Merancang suatu cara untuk menyelesaikan masalah.

c. Mengorganisasikan unsur - unsur atau bagian - bagian menjadi struktur baru yang belum pernah ada

\begin{tabular}{|c|c|c|c|c|c|c|c|c|c|c|}
\hline & & \multicolumn{2}{|c|}{$\begin{array}{l}\text { Levones Test for Equalty of } \\
\text { variances }\end{array}$} & \multicolumn{7}{|c|}{ Hest sor Equain of Means } \\
\hline & & \multirow[b]{2}{*}{ f } & \multirow[b]{2}{*}{$8 i q$} & \multirow[b]{2}{*}{$t$} & \multirow[b]{2}{*}{ at } & \multirow[b]{2}{*}{$\operatorname{sig} .(2 \tan 6 \sin )$} & \multirow{2}{*}{$\begin{array}{c}\text { Mean } \\
\text { Dittarence }\end{array}$} & \multirow{2}{*}{$\begin{array}{l}\text { S11 Ence } \\
\text { Drferente }\end{array}$} & \multicolumn{2}{|c|}{$\begin{array}{l}958 \text { Contdente interval of thin } \\
\text { Diference }\end{array}$} \\
\hline & & & & & & & & & LOWER & Goper \\
\hline HDTe,Postant & $\begin{array}{l}\text { Eqaal vanances } \\
\text { assumed }\end{array}$ & .604 & 950 & 8517 & 56 & .000 & $2+78$ & 256 & 1.606 & 2.690 \\
\hline & $\begin{array}{l}\text { Equai waiances not } \\
\text { assumed }\end{array}$ & & & 8476 & $62598:$ & .000 & 2.178 & 257 & 1662 & 2.693 \\
\hline
\end{tabular}

Gambar 3: Perbedaan HOTS Mahasiswa Pada Kelas Eksperimen dan Kelas Kontrol

Berdasarkan hasil analisis data tes pada gambar 3, diperoleh hasil bahwa terdapat perbedaan keterampilan berpikir tingkat tinggi (HOTS) mahasiswa antara kelas eksperimen dan kelas kontrol. Hasil perbedaan tersebut ditunjukkan dengan nilai sig. (2-tailed) $0,000<\alpha=0,05$. Dengan demikian, dapat disimpulkan bahwa penerapan model pembelajaran multiliterasi dapat meningkatkan keterampilan berpikir tingkat tinggi (HOTS) mahasiswa. Hasil uji peningkatan keterampilan berpikir tingkat tinggi (HOTS) mahasiswa kelas eksperimen dan kelas kontrol disajikan pada tabel 1 berikut.

Tabel 1. Hasil N-Gain HOTS Kelas Eksperimen dan Kontrol

\begin{tabular}{ccc}
\hline Kelas & Kelas eksperimen & Kontrol \\
\hline Rata-rata pretest & $\mathbf{4}$ & $\mathbf{3}$ \\
\hline Rata-rata posttest & $\mathbf{7}$ & $\mathbf{5}$ \\
\hline Gain & $\mathbf{0 , 6 1}$ & $\mathbf{0 , 3 1}$ \\
\hline Keterangan & Sedang & Sedang \\
\hline
\end{tabular}

Berdasarkan Tabel 1, hasil N- gain pada kelas eksperimen diperoleh rata-rata pretest sebesar 4 dan ratarata posttest sebesar 7 dengan nilai $\mathrm{N}$-Gain 0,61 . Sedangkan pada kelas kontrol diperoleh rata-rata pretest 3 dan rata-rata posttest 5 dengan nilai $\mathrm{N}$-Gain 0,31. Pada dasarnya kelas eksperimen dan kelas kontrol memperoleh nilai $\mathrm{N}-$ Gain dalam kategori sedang, namun nilai $\mathrm{N}$-Gain pada kelas kontrol lebih kecil daripada kelas eksperimen. Dengan kata lain, keterampilan berpikir tingkat tinggi (HOTS) mahasiswa kelas eksperimen mengalami peningkatan yang lebih baik dibandingkan dengan kelas kontrol yang ditunjukkan dengan perolehan nilai N-Gain yang lebih besar dari pada kelas kontrol.

Penerapan model pembelajaran multiliterasi dapat dikatakan sebagai salah satu model pembelajaran yang mampu untuk meningkatkan keterampilan berpikir tingkat tinggi mahasiswa. Kompetensi multiliterasi merupakan kondisi ketika seseorang memiliki kemampuan memanfaatkan beragam bentuk informasi secara bijaksana dan cerdas. Sebagaimana penelitian terdahulu yang menemukan bahwa pembelajaran yang dilaksanakan berdasarkan pedagogi multiliterasi dan pemanfaatan teknologi dapat memfasilitasi pengalaman 
5973 Penerapan Model Pembelajaran Multiliterasi untuk Meningkatkan Keterampilan Berpikir Tingkat Tinggi (HOTS) Mahasiswa Pendidikan Guru Sekolah Dasar - Khoimatun, Asrizal Wahdan Wilsa DOI: https://doi.org/10.31004/basicedu.v5i6.1603

belajar yang bermakna bagi siswa dan membantu siswa mencapai kemampuan multiliterasinya (Cooper et al., 2013). Pembelajaran yang bersifat multiliterasi menggunakan strategi literasi dalam pembelajaran dengan memadukan keterampilan abad ke-21 (keterampilan berpikir tingkat tinggi) diharapkan dapat menjadi bekal kecakapan hidup sepanjang hayat (Pendidikan \& Kebudayaan, 2018). Hal tersebut sejalan dengan penelitian Untari (2017) yang menyimpulkan bahwa pentingnya kemampuan mahasiswa dalam pembelajaran multiterasi dalam menghadapi perubahan kurikulum khususnya kurikulum 2013 menjadi bekal sebagai tenaga pendidik yang memiliki standar kompetensi tinggi. Sementara itu, penelitian Syaripudin (2019) menyatakan bahwa dalam konteks pendidikan, keterampilan abad 21, multiliterasi dan keterampilan berpikir tingkat tinggi pada dasarnya merupakan tantangan yang harus segera diatasi. Pendidikan harus disesuaikan dengan tantangan tersebut. Senada dengan itu, Carel et al. (2018) menyimpulkan bahwa terdapat peningkatan kemampuan HOTS siswa dengan pembelajaran multiliterasi matematis lebih baik dari pembelajaran konvensional.

Pada tahap pembelajaran multiliterasi mahasiswa pada kemampuan HOTS terdapat peningkatan sesuai dengan kemampuan berpikir tingkat tinggi melibatkan analisis (C4), mengevaluasi (C5), dan mencipta atau kreativitas (C6), (Krathworl and Anderson dalam Rosari, 2018). Menurut Brookhart (2010) kemampuan berpikir tingkat tinggi (HOTS) adalah (1) berpikir tingkat tinggi berada pada bagian atas taksonomi kognitif Bloom, (2) tujuan pengajaran di balik taksonomi kognitif yang dapat membekali peserta didik untuk melakukan transfer pengetahuan, (3) mampu berpikir artinya peserta didik mampu menerapkan pengetahuan dan keterampilan yang mereka kembangkan selama belajar pada konteks yang baru. Dalam hal ini yang dimaksud "baru" adalah aplikasi konsep yang belum terpikirkan sebelumnya oleh peserta didik, namun konsep tersebut sudah diajarkan, ini berarti belum tentu sesuatu yang universal baru. Berpikir tingkat tinggi berarti kemampuan peserta didik untuk menghubungkan pembelajaran dengan hal-hal lain yang belum pernah diajarkan (Istiyono \& Mardapi, 2014). Atau dengan kata lain, berpikir tingkat tinggi adalah proses berpikir kompleks dalam menguraikan materi, membuat kesimpulan, membangun representasi, menganalisis, dan membangun hubungan dengan melibatkan aktivitas mental yang paling dasar (Resnick dalam Ariyana et al., 2018).

\section{KESIMPULAN}

Berdasarkan analisis data dan pembahasan, diperoleh simpulan sebagai berikut: (1) Terdapat perbedaan keterampilan berpikir tingkat tinggi (HOTS) mahasiswa kelas eksperimen dan kontrol setelah diterapkannya model pembelajaran multiliterasi; (2) Terdapat perbedaan keterampilan berkolaborasi mahasiswa kelas eksperimen dan kontrol setelah diterapkannya model pembelajaran multiliterasi; dan (3) Terdapat pengaruh keterampilan berkolaborasi terhadap keterampilan berpikir tingkat tinggi (HOTS) mahasiswa.

Model pembelajaran multiliterasi merupakan suatu paradigma baru yang dapat diterapkan dan dikembangkan untuk meningkatkan berbagai keterampilan mahasiswa. Dengan menggunakan model pembelajaran multiliterasi dalam proses pembelajaran, mahasiswa akan memperoleh pengalaman belajar yang lebih bermakna karena dengan multiliterasi, mahasiswa akan menempatkan kemampuan membaca, menulis, menyimak, dan berbicara seefisien mungkin untuk meningkatkan kemampuan berpikir meliputi kemampuan mengkritisi, menganalisis, dan mengevaluasi informasi dari berbagai sumber dalam berbagai ragam disiplin ilmu dan kemampuan mengkomunikasikan informasi tersebut.

\section{UCAPAN TERIMA KASIH}

Ucapan terima kasih ditujukan kepada: (1) Kementrian Riset dan Teknologi Pendidikan Tinggi; (2) Yayasan Darul Ma'arif Indramayu; (3) Ketua STKIP Nahdlatul Ulama Indramayu; (4) Ketua Program Studi Pendidikan Guru Sekolah Dasar STKIP Nahldatul Ulama Indramayu. 
5974 Penerapan Model Pembelajaran Multiliterasi untuk Meningkatkan Keterampilan Berpikir Tingkat Tinggi (HOTS) Mahasiswa Pendidikan Guru Sekolah Dasar - Khoimatun, Asrizal Wahdan Wilsa DOI: https://doi.org/10.31004/basicedu.v5i6.1603

\section{DAFTAR PUSTAKA}

Abidin, Yunus. (2016). Desain Sistem Pembelajaran Dalam Konteks Kurikulum 2013. //Library.Fmipa.Uny.Ac.Id/Opac/Index.Php?P=Show_Detail\&Id=7725\&Keywords=

Abidin, Yunus. (2014). Desain Sistem Pembelajaran Dalam Konteks Kurikulum 2013. Refika, Aditama.

Ariyana, Y., Ari Pudjiastuti Mpd Reisky Bestary, M., \& Zamroni, Mp. (2018). Buku Pegangan Pembelajaran Berorientasi Pada Keterampilan Berpikir Tingkat Tinggi.

Brookhart, S. M. (2010). How To Assess Higher-Order Thinking Skills In Your Classroom. Www.Ascd.Org/Memberbooks

Carel, G., Sugiarni, R., Algifari, E., \& Yastrib, H. (2018). Implementasi Pilar-Pilar Budaya Cianjur Dalam Pembelajaran Multiliterasi Matematis Berbantuan Teknologi Smartphone (Geogebra Versi Android) Untuk Meningkatkan Kemampuan Higher Order Thinking Skill (Hots) Siswa Sekolah Kejuruan. In Prisma (Vol. 70, Issue 1). Https://Jurnal.Unsur.Ac.Id/Prisma

Cooper, N., Lockyer, L., \& Brown, I. (2013). Developing Multiliteracies In A Technology-Mediated Environment. $\quad H t t p s: / / D o i . O r g / 10.1080 / 09523987.2013 .795350, \quad$ 50(2), 93-107. Https://Doi.Org/10.1080/09523987.2013.795350

Dafit, F. (2017). Pengaruh Model Pembelajaran Multiliterasi Terhadap Kemampuan Membaca Siswa Sekolah Dasar. Jurnal Inovasi Pendidikan Dan Pembelajaran Sekolah Dasar, 1(1), 87-100.

Dinni, H. N. (2018). Hots (High Order Thinking Skills) Dan Kaitannya Dengan Kemampuan Literasi Matematika. In Prisma, Prosiding Seminar Nasional Matematika, 170-176. Https://Journal.Unnes.Ac.Id/Sju/Index.Php/Prisma/

Hartati, T. (2020). Pembelajaran Di Sekolah Dasar Dari Prespektif Multiliterasi Dan Keterampilan Berpikir Tingkat Tinggi (Kbtt). Jurnal Inovasi Sekolah Dasar, 7(2). Https://Doi.Org/10.36706/Jisd.V7i2.13251

Istiyono, E., \& Mardapi, D. (2014). Pengembangan Tes Kemampuan Berpikir Tingkat Tinggi Fisika (Pysthots) Peserta Didik Sma 1). Jurnal Penelitian Dan Evaluasi Pendidikan, 18(1), 1-12.

Krathwohl, D. R. (2002). A Revision Of Bloom's Taxonomy: An Overview. Theory Into Practice, 41(4), 212-218. Https://Doi.Org/10.1207/S15430421 tip4104_2

Kurniasih, K. (2019). Development Of Multiliteration And Higher Order Thinking Skills Through Integrated Learning. International Journal Of Science And Applied Science: Conference Series, 3(1), 69-74. Https://Doi.Org/10.20961//jsascs.V3i1.32532

Pendidikan, K., \& Kebudayaan, D. (2018). Strategi Literasi Dalam Pembelajaran Di Sekolah Menengah Pertama (Materi Penyegaran Instruktur Kurikulum 2013). Satgas Gls Ditjen Dikdasmen.

Purbaningrum, K. A. (2017). Kemampuan Berpikir Tingkat Tinggi Siswa Smp Dalam Pemecahan Masalah Matematika Ditinjau Dari Gaya Belajar. Jppm (Jurnal Penelitian Dan Pembelajaran Matematika), $10(2), 40-49$.

Rahman, F. A., \& Damaianti, V. S. (2019). Model Multiliterasi Kritis Dalam Pembelajaran Siswa Sekolah Dasar. Jpd: Jurnal Pendidikan Dasar, 10(1), 27-34. Https://Doi.Org/10.21009/Jpd.010.03

Rosari, E. F. F. (2018). Pengembangan Instrumen Penilaian Berbasis Hots Pada Kompetensi Dasar Menerapkan Posting Kelas X Akuntansi Smk.

Swatika Sari, E., Suryaman, M., \& Lestyarini Beniati. (2013). Model Multiliterasi Dalam Perkuliahan Pendidikan Bahasa Dan Sastra Indonesia. Litera, 12(12), 246-255.

Syaripudin, T. (2019). Multiliteration And Higher Order Thinking Skills Implications To Education. International Journal of Science And Applied Science: Conference Series, 3(1), 131. Https://Doi.Org/10.20961//jsascs.V3i1.32534

Untari, E. (2017). Pentingnya Pembelajaran Multiliterasi Untuk Mahasiswa Pendidikan Guru Sekolah Dasar 
5975 Penerapan Model Pembelajaran Multiliterasi untuk Meningkatkan Keterampilan Berpikir Tingkat Tinggi (HOTS) Mahasiswa Pendidikan Guru Sekolah Dasar - Khoimatun, Asrizal Wahdan Wilsa DOI: https://doi.org/10.31004/basicedu.v5i6.1603

Dalam Mempersiapkan Diri Menghadapi Kurikulum 2013. Wahana Sekolah Dasar, 25(1), 16-22.

Widodo, T., \& Kadarwati, S. (2013). Higher Order Thinking Berbasis Pemecahan Masalah Untuk Meningkatkan Hasil Belajar Berorientasi Pembentukan Karakter Siswa. Jurnal Cakrawala Pendidikan, 5(1), 161-171. 